\title{
Selection of Trichoderma spp. strains for the control of Sclerotinia sclerotiorum in soybean
}

\author{
Patrícia Elias Haddad(1), Luis Garrigós Leite(2), Cleusa Maria Mantovanello Lucon ${ }^{(1)}$ and Ricardo Harakava(1) \\ (1)Instituto Biológico, Avenida Conselheiro Rodrigues Alves, no 1.252, Vila Mariana, CEP 04114-900 São Paulo, SP, Brazil. E-mail: \\ patriciaehaddad@yahoo.com.br, mantova@biologico.sp.gov.br, harakava@biologico.sp.gov.br (2)Instituto Biológico, Centro Experimental, \\ Alameda dos Vidoeiros, no 1.097, Gramado, CEP 13101-680 Campinas, SP, Brazil. E-mail: Igleite@biologico.sp.gov.br
}

\begin{abstract}
The objective of this work was to evaluate, in vitro and in vivo, the potential of Trichoderma spp. strains to control Sclerotinia sclerotiorum in soybeans (Glycine max) and to perform the molecular identification of the best performing strains. The effect of 120 strains of Trichoderma spp. on the viability of $S$. sclerotiorum sclerotia was evaluated in vitro through immersion in suspension of conidia from the antagonists and plating in culture medium. The best performing strains were evaluated in vivo, in a greenhouse, for control of the pathogen inoculated on 'Pintado' soybean seeds and plants. Of the 120 strains tested in vitro, 22 strains of Trichoderma spp. caused $100 \%$ inhibition of sclerotia germination. In the greenhouse, five strains inhibited the negative effect of the pathogen on seed germination and two strains increased in up to $67 \%$ plant dry matter. The best performing strains were identified as T. koningiopsis (3 strains), T. asperelloides (3), T. atroviride (2), and T. virens (1). Trichoderma strains are able to protect soybean plants from the harmful effect of $S$. sclerotiorum and, at the same time, they can promote the growth of the aerial part in greenhouse conditions.
\end{abstract}

Index terms: Glycine max, biological control, DNA sequencing, sclerotia, white mold.

\section{Seleção de estirpes de Trichoderma spp. para o controle de Sclerotinia sclerotiorum em soja}

\begin{abstract}
Resumo - O objetivo deste trabalho foi avaliar, in vitro e in vivo, o potencial de isolados de Trichoderma spp. no controle de Sclerotinia sclerotiorum em soja (Glycine max) e identificar molecularmente as estirpes que mais se destacaram. O efeito de 120 isolados de Trichoderma spp. sobre a viabilidade de escleródios de $S$. sclerotiorum foi avaliado in vitro, por imersão em suspensão de conídios dos antagonistas e plaqueamento em meio de cultura. As estirpes que mais se destacaram foram avaliadas, in vivo, em casa de vegetação, no controle do patógeno em plantas e sementes de soja 'Pintado'. Dos 120 isolados testados in vitro, 22 inibiram em $100 \%$ a germinação de escleródios. Em casa de vegetação, cinco estirpes inibiram os efeitos prejudiciais do patógeno na germinação das sementes e duas estirpes proporcionaram aumento de até $67 \%$ na massa de matéria seca das plantas. As melhores estirpes foram identificadas como T. koningiopsis (3 estirpes), T. asperelloides (3), T. atroviride (2) e T. virens (1). Trichoderma spp. conseguem proteger plantas de soja 'Pintado' do efeito prejudicial de $S$. sclerotiorum ao mesmo tempo em que podem promover o crescimento da parte aérea em condições de casa de vegetação.
\end{abstract}

Termos para indexação: Glycine max, controle biológico, sequenciamento de DNA, escleródios, mofo branco.

\section{Introduction}

Soybean [Glycine $\max$ (L.) Merr.] is the most important oleaginous plant cultivated. In Brazil, this crop is one of the main agricultural commodities that contributes to a positive commercial balance. Diseases, such as white mold caused by the fungus Sclerotinia sclerotiorum (Lib.) de Bary, are one of the main limiting factors that limit full productivity. S. sclerotiorum is a pathogen of more than 400 plant species, including several of economic importance (Abdullah et al., 2008). This fungus strives in mild temperatures and high humidity conditions and survives in soil and crop remains through its resistant-structure sclerotia. Control methods involve cultural practices, use of resistant cultivars, and chemical control (Bardin \& Huang, 2001). Alternative methods such as biological control, are also being employed and must be used when sclerotia are in a resting state in the soil or in the germinating 
stage, when the pathogen is most vulnerable in the environment (Zancan et al., 2012).

Trichoderma spp. consists of a large group of fungi important for biological control. They are found in most ecosystems as plant root colonizers and display several mechanisms that can be used to control phytopathogens such as antibiosis, mycoparasitism, competition, and induction of plant resistance (Consolo et al., 2012). Several species of Trichoderma have shown promising results for control of $S$. sclerotiorum (Smith et al., 2013; Tančić et al., 2013; Smolińska et al., 2016). Sclerotinia sclerotiorum and Sclerotinia cepivorum had their growth inhibited in vitro in up to $81.5 \%$, and cucumber plants could be protected against $S$. sclerotiorum in greenhouse trials using Trichoderma strains (Ethur et al., 2005; Hernandez Castillo et al., 2011). These results have drawn scientific attention to Trichoderma spp. during the last decades and conferred it broad acceptance as a biological control agent (Schuster \& Schmoll, 2010). The demand for biological control agents has increased significantly in recent years (Lucon, 2008), sharing the need for further investigation to provide more options for the control of plant diseases, including the highly impacting white mold disease of soybean.

The objective of this work was to evaluate, in vitro and in vivo, the potential of Trichoderma spp. strains to control Sclerotinia sclerotiorum in soybeans and to perform the molecular identification of the best performing strains.

\section{Material and Methods}

The experiments were carried out at the phytopathological biochemistry laboratory of Instituto Biológico, located in the munipality of São Paulo, in the state of São Paulo, Brazil, between January 2013 and February 2014. One hundred and twenty strains of Trichoderma spp., from the Mario Barreto Figueiredo fungi collection of Instituto Biológico, were subjected to the in vitro assay. Inocula of Trichoderma spp. strains were produced on autoclaved rice in plastic bags incubated for seven days at $25 \pm 2^{\circ} \mathrm{C}$ under a 12-hour photoperiod. The LQC 122 S. sclerotiorum strain was obtained from the culture collection of Embrapa Meio Ambiente. Sclerotia of the pathogen were multiplied in maize flour-enriched carrot medium (Ferraz \& Café Filho, 1998) for 30 days at $21^{\circ} \mathrm{C}$.
For the in vitro inhibiton of sclerotia germination assay, sclerotia of the pathogen were submersed in conidial suspensions of strains of Trichoderma spp. $\left(1 \times 10^{7}\right.$ conidia per $\left.\mathrm{mL}\right)$ for $30 \mathrm{~min}$. Treated sclerotia were placed on moistened autoclaved filter paper inside Petri dishes and incubated at $25 \pm 2^{\circ} \mathrm{C}$ during one week under a 12-hour photoperiod. After incubation, sclerotia were surface sterilized by immersion in $50 \%$ ethanol for $3 \mathrm{~min}$ and 1\% sodium hypochlorite for 3 min, followed by three washes in autoclaved distilled water, and placed on BDA medium for incubation during another week at $25 \pm 2^{\circ} \mathrm{C}$. The control treatment consisted of submersion of sclerotia in autoclaved distilled water only. The experimental design was completely randomized with three replicates of five sclerotia each. The effect on the pathogen was evaluated by counting the number of viable sclerotia, which were able to germinate within eight days after plating on BDA (Görgen et al., 2009). The 22 strains of Trichoderma spp. that caused in $100 \%$ inhibiton of the pathogen in the first trial were tested again three more times.

The effect of the strains of Trichoderma spp. on soybean seeds germination was evaluated by in vitro and in vivo assays. In the in vitro assay, nine strains of Trichoderma spp. were randomly selected among the 22 strains selected previously. 'Pintado' soybean seeds were submersed in conidial suspensions at the concentrations of $10^{6}$ and $10^{7}$ per $\mathrm{mL}$ for a few minutes and incubated on filter paper moistened with autoclaved distilled water inside Petri dishes. The control treatment consisted of seeds submersed in autoclaved distilled water only. Each strain was considered as one treatment, with three replicates of 20 seeds in each. Plates were incubated at $25 \pm 2^{\circ} \mathrm{C}$ during six days under a 12-hour photoperiod. After incubation, germinated seeds were counted for each treatment/strain.

For the in vivo assay in the greenhouse, four strains of Trichoderma spp. were randomly selected. These were grown on autoclaved rice grains and incorporated into $700 \mathrm{~g}$ of autoclaved commercial substrate Tropstrato Hortaliça 2 (Vida Verde, São Paulo, SP, Brazil) in plastic pots. Three concentrations of Trichoderma spp. inocula were evaluated: $0.25,0.5$, and $1.0 \%(\mathrm{w} / \mathrm{v})$. Each treatment/strain had five replicates (pots) with three seeds each. The control treatment consisted of autoclaved rice grains without Trichoderma spp. Pots were kept in the greenhouse under natural conditions,

Pesq. agropec. bras., Brasília, v.52, n.12, p.1140-1148, dez. 2017 DOI: $10.1590 / \mathrm{S} 0100-204 \mathrm{X} 2017001200002$ 
and germinated seeds were counted 4,5 , and 6 days after sowing. Both in vitro and in vivo assays had a completely randomized design.

The biological control assays were conducted in the greenhouse between June 2013 and February 2014. Nine strains of Trichoderma spp. were employed: IB $10 / 12$, IB $07 / 01$, IB 30/12, IB 37/12, IB 62/12, IB 91/12, IB 103/12, IB 111/12, and IB 119/12. The pathogenicity of the LQC 122 S. sclerotiorum strain was verified by inoculation of the third trifoliate removed from 'Pintado' soybean plants. Leaves were kept on moistened filter paper in Petri dishes, and a 5-mm mycelium plug of $S$. sclerotiorum was placed on the adaxial surface of the middle leaf next to the midvein. Plates were incubated at room temperature in the dark, and the presence of lesions was checked 48, 66, and 90 hours after inoculation. Ten replicates per plate were evaluated. The control treatment consisted of inoculation with the plug of BDA medium without fungal growth.

For the biological control assay, plastic pots containing $800 \mathrm{~g}$ of commercial substrate (Tropstrato Hortaliça 2) were infested with $16 \mathrm{~g}$ of S. sclerotiorum inoculum and kept in moist chamber for seven days at $22^{\circ} \mathrm{C}$. After this period, $16 \mathrm{~g}$ of rice grains colonized by each strain of Trichoderma spp. were incorporated to the infested substrate and six 'Pintado' soybean seeds were planted in each pot, with five replicates per pot for each strain. The control treatments consisted of plants inoculated with the pathogen only (infected control) and plants treated with rice grains without Trichoderma spp. and without pathogen (untreated control). One week after sowing, three plantlets were removed from each pot. The effect of strains of Trichoderma was evaluated by counting germinated seeds one week after sowing, and by determining the incidence of white mold and the weight of above-ground dry matter 35 days after sowing. Root dry matter was not measured since above-ground development reflects root system condition (Björkman et al., 1998). Experiments were repeated three times, data were subjected to analysis of variance and compared by the Scott-Knott test, at $5 \%$ probability, using the Assistat software, version 7.5 Beta (Silva \& Azevedo, 2006).

At the end of the assay, the ability of the strains of Trichoderma spp. to colonize plant roots was verified. Three roots were randomly collected from each treatment, and washed with tap water; $2-\mathrm{cm}$ fragments were incubated on BDA medium amended with antibiotics $[0.17 \mathrm{~g}$ ampicillin, $0.05 \mathrm{~g}$ of pentabiotico (commercial mix of benzylpenicillin and streptomycin) for $1 \mathrm{~L}$ of medium] and $0.01 \%$ Triton X100 to limit colony expansion. Positive colonization was observed by visualization of Trichoderma spp. growth along the root fragments.

Nine strains of Trichoderma spp. were subjected to molecular identification by sequencing part of the translation elongation factor (TEF) gene. Polymerase chain reaction (PCR) was performed with primers $\left(5^{\prime}\right.$ - CAAAATGGGTAAGGAGGASAAGAC - 3') and tef997R (5' - CAGTACCGGCRGCRATRATSAG 3') (Shoukouhi \& Bisset, 2009). The PCR amplification program consisted of initial denaturation at $94^{\circ} \mathrm{C}$ per 2 min followed by 40 cycles of $94^{\circ} \mathrm{C}$ per $30 \mathrm{~s}-54^{\circ} \mathrm{C}$ per 30 $\mathrm{s}-72^{\circ} \mathrm{C}$ per $60 \mathrm{~s}$, and final extension at $72^{\circ} \mathrm{C}$ per $4 \mathrm{~min}$. Sequencing reaction was performed with the Big Dye 3.1 reagent (Applied Biosystems Inc., Foster City, CA, USA) and analyzed in a capillary automatic sequencer ABI 3500XL (Applied Biosystems, Foster City, USA). Sequences deposited in the GenBank by authors of recognized reputation in Trichoderma taxonomy were retrieved for construction of a phylogenetic tree. This tree was constructed by the maximum likelihood method based on Kimura 2-parameter model with 1000 bootstrap replicates using the Mega software, version 6.0 (Tamura et al., 2013).

\section{Results and Discussion}

The LQC 122 Sclerotinia sclerotiorum strain was pathogenic to 'Pintado' soybean. Symptoms were first observed on trifoliate leaves 48 hours after inoculation and increased progressively with time. Pathogenicity results are in alignment with the observations of Garcia \& Juliatti (2012).

Sixty six out of the 120 strains of Trichoderma spp. tested have shown the ability to reduce sclerotia germination more than $50 \%$ and 22 inhibited germination completely. Similar results were obtained by Smith et al. (2013), who, among 22 strains of Trichoderma spp. observed sclerotia inhibition rate of 75 to $80 \%$. Görgen et al. (2009) considered the colonization of $S$. sclerotiorum sclerotia by T. harzianum as a form of parasitism and classified sclerotia that did not show myceliogenic germination as unviable. Abdullah et al. (2008) also attributed 
the inhibition germination of $S$. sclerotiorum to the mycoparasitism of $T$. harzianum. Mycoparasitism is a complex mechanism triggered by the presence of phytopathogenic fungus, envolving the secretion of hydrolytic enzymes, mainly chitinases, glucanases, and proteases that allow Trichoderma spp. hyphae to penetrate hyphae of the host (Reithner et al., 2011).

No significant differences were observed when the two concentrations of Trichoderma spp. inocula, $10^{6}$ and $10^{7}$ conidia per $\mathrm{mL}$, were compared in vitro seed germination inhibition test, except for strains IB 69/12 (lower germination at 107) and IB 91/12 (higher germination at 107) (Figure 1). Four strains, IB 10/12, IB 37/12, IB 62/12, and UB 91/12, decreased seed germination in at least one of the inoculum concentrations. In the in vivo seed germination inhibition test performed in pots with substrate, none of the strains interfered in seed germination six days after sowing, although a delaying effect could be observed for some strains the fourth and fifth days (Figure 2). Ousley et al. (1993) observed that some strains of Trichoderma spp. can inhibit lettuce (Lactuca sativa

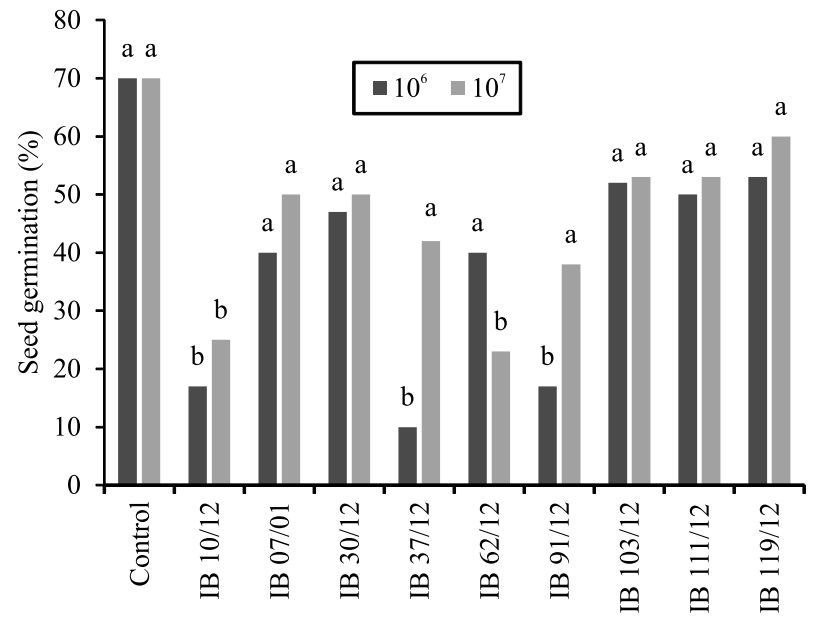

Figure 1. Effect of strains of Trichoderma spp. on 'Pintado' soybean (Glycine max) seed germination in vitro (Petri dishes). Seeds were treated with conidial suspensions at concentrations of $10^{6}$ and $10^{7}$ per $\mathrm{mL}$. In the control, seeds were treated with autoclaved water. Values are presented as percentage of germinated seeds $(n=20)$. Data presented are the means of 3 repetitions. Values indicated by equal letters do not differ significantly by the Scott-Knott test, at $5 \%$ probability.

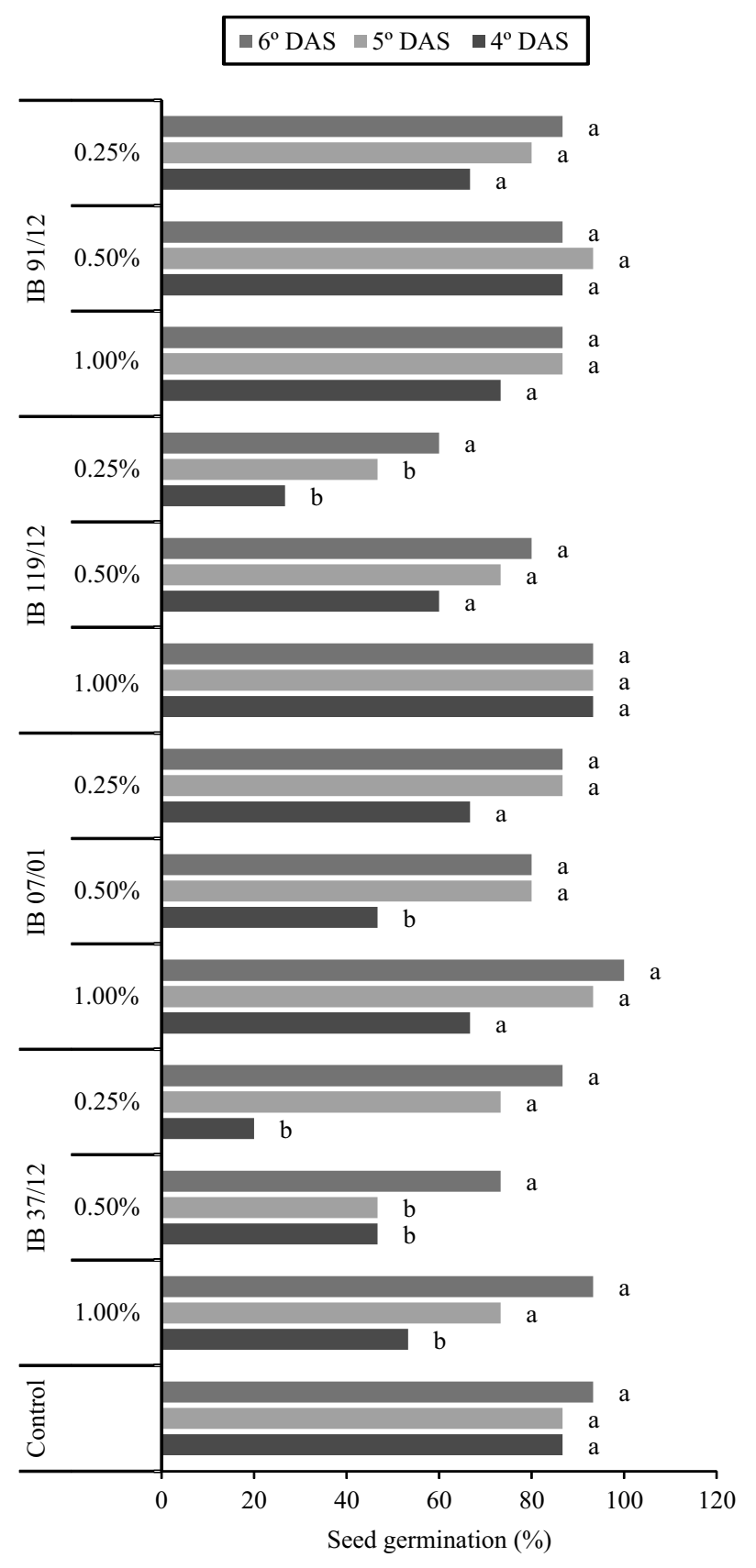

Figure 2. Effect of strains of Trichoderma spp. on 'Pintado' soybean (Glycine max) seed germination in vivo (pots with substrate). Strains of Trichoderma spp. were grown on autoclaved rice grains and incorporated to the substrate at the concentrations of $0.25,0.5$, and $1.0 \%$ (weight/ volume). The control treatment consisted of autoclaved rice grains without Trichoderma spp. Values are presented as percentage of germinated seeds $(n=3)$. Data presented are the means of 5 repetitions. Values indicated by equal letters do not differ significantly by the Scott-Knott test, at 5\% probability. DAS, days after sowing.

Pesq. agropec. bras., Brasília, v.52, n.12, p.1140-1148, dez. 2017 DOI: $10.1590 / \mathrm{S} 0100-204 \mathrm{X} 2017001200002$ 
L.) seed germination but also enhance the growth of the plant. According to the authors, the results are highly depend on strain, method of inoculum application and preparation.

In the biological control assay performed in the greenhouse, typical white mold symptoms could not be observed on the inoculated plants; however, the presence of strains of Trichoderma spp. on the substrate increased seed germination in the presence of the pathogen in at least one of the experimental replicates (Table 1). Differences between treatments could not be observed in the first experiment. Five strains reduced seed germination inhibition by the pathogen in the second experiment and all strains had this effect in the third experiment. Strains IB 07/01 and IB 37/12 had the best performance when the last two experiments were considered. Six strains enhanced seed germination even in the absence of the pathogen in the third experiment. Tančić et al. (2013) also found improvement in soybean seed germination, emergence, and vigor subjected to treatment with Trichoderma spp. Brotman et al. (2013) reported increase in the emergence and dry matter of Arabidopsis thaliana and cucumber grown on soil

Table 1. 'Pintado' soybean (Glycine max) germinated seeds in substrate infested with Sclerotinia sclerotiorum in the presence or absence of strains of Trichoderma spp.(1).

\begin{tabular}{lccc}
\hline Treatment & $\begin{array}{c}\text { First assay } \\
\text { June 2013 }\end{array}$ & $\begin{array}{c}\text { Second assay } \\
\text { December 2013 }\end{array}$ & $\begin{array}{c}\text { Third assay } \\
\text { January 2014 }\end{array}$ \\
\hline Infected control $^{(2)}$ & $4.2 \mathrm{a}$ & $2.6 \mathrm{~b}$ & $3.0 \mathrm{c}$ \\
Control $^{(3)}$ & $4.2 \mathrm{a}$ & $4.4 \mathrm{a}$ & $4.2 \mathrm{~b}$ \\
IB 10/12 & $4.4 \mathrm{a}$ & $4.6 \mathrm{a}$ & $4.0 \mathrm{~b}$ \\
IB 07/01 & $4.4 \mathrm{a}$ & $5.2 \mathrm{a}$ & $5.0 \mathrm{a}$ \\
IB 30/12 & $4.2 \mathrm{a}$ & $3.4 \mathrm{~b}$ & $4.8 \mathrm{a}$ \\
IB 37/12 & $4.6 \mathrm{a}$ & $4.8 \mathrm{a}$ & $4.7 \mathrm{a}$ \\
IB 62/12 & $4.4 \mathrm{a}$ & $3.2 \mathrm{~b}$ & $4.5 \mathrm{a}$ \\
IB 91/12 & $4.4 \mathrm{a}$ & $3.6 \mathrm{~b}$ & $4.8 \mathrm{a}$ \\
IB 103/12 & $4.6 \mathrm{a}$ & $3.4 \mathrm{~b}$ & $4.7 \mathrm{a}$ \\
IB 111/12 & $4.2 \mathrm{a}$ & $4.8 \mathrm{a}$ & $4.3 \mathrm{~b}$ \\
IB 119/12 & $4.4 \mathrm{a}$ & $4.2 \mathrm{a}$ & $4.2 \mathrm{~b}$ \\
\hline CV (\%) & 13.65 & 25.22 & 12.17 \\
\hline
\end{tabular}

(1) Means followed by equal letters, in the columns do not differ significantly by the Scott-Knott test, at $5 \%$ probability. ${ }^{(2)}$ Infected control, plants inoculated with S. sclerotiorum. ${ }^{(3)}$ Control, plants not inoculated with either pathogen or strains of Trichoderma spp. CV, coefficient of variation. amended with Trichoderma spp. The results obtained corroborate those of Benítez et al. (1998), who showed that Trichoderma spp. synthesize growth factors that increase seed germination rate. The absence of effect of strains of Trichoderma spp. in the first experiment can be explained by the low temperatures (average $19.1^{\circ} \mathrm{C}$ ) observed in June 2013. Several abiotic factors, such as temperature and humidity, can affect the activity of Trichoderma spp., which are better adapted to temperatures between 25 and $30^{\circ} \mathrm{C}$ (Bomfim et al., 2010; Akrami et al., 2011).

Most strains of Trichoderma spp. promoted an increase in above-ground dry matter in the three biological control experiments in the presence of the pathogen (Table 2). The highest levels were observed for strains IB 103/12 (56\%), IB 37/12 (33\%), and IB 07/01 $(30 \%)$ in the first experiment; IB 07/01 (61\%), IB 10/12 (28\%), and IB 62/12 (27\%) in the second experiment; and IB 62/12 (67\%), IB 91/12 (63\%), and IB 111/12 $(53 \%)$ in the third experiment. Therefore, soybean plants had better development on substrate infected with $S$. sclerotiorum when strains of Trichoderma spp.

Table 2. Above-ground dry matter weight (DMW) of 'Pintado' soybean (Glycine max) grown on substrate infested with Sclerotinia sclerotiorum in the presence or absence of strains of Trichoderma spp..$^{(1)}$.

\begin{tabular}{lccc}
\hline Treatment & $\begin{array}{c}\text { First assay } \\
\text { June 2013 } \\
\text { DMW (g) }\end{array}$ & $\begin{array}{c}\text { Second assay } \\
\text { December 2013 } \\
\text { DMW (g) }\end{array}$ & $\begin{array}{c}\text { Third assay } \\
\text { January 2014 } \\
\text { DMW (g) }\end{array}$ \\
\hline Infected control $^{(2)}$ & $0.877 \pm 0.04 \mathrm{~d}$ & $0.8780 \pm 0.026 \mathrm{c}$ & $0.5156 \pm 0.012 \mathrm{~d}$ \\
Control $^{(3)}$ & $1.051 \pm 0.07 \mathrm{c}$ & $0.7239 \pm 0.056 \mathrm{~d}$ & $0.7657 \pm 0.027 \mathrm{~b}$ \\
IB 10/12 & $0.901 \pm 0.07 \mathrm{~d}$ & $1.1306 \pm 0.033 \mathrm{~b}$ & $0.6423 \pm 0.029 \mathrm{c}$ \\
IB 07/01 & $1.143 \pm 0.03 \mathrm{~b}$ & $1.4202 \pm 0.040 \mathrm{a}$ & $0.7076 \pm 0.028 \mathrm{~b}$ \\
IB 30/12 & $1.068 \pm 0.01 \mathrm{c}$ & $0.9533 \pm 0.092 \mathrm{c}$ & $0.7361 \pm 0.049 \mathrm{~b}$ \\
IB 37/12 & $1.170 \pm 0.03 \mathrm{~b}$ & $1.0112 \pm 0.062 \mathrm{c}$ & $0.7585 \pm 0.052 \mathrm{~b}$ \\
IB 62/12 & $0.997 \pm 0.03 \mathrm{c}$ & $1.1219 \pm 0.066 \mathrm{~b}$ & $0.8633 \pm 0.028 \mathrm{a}$ \\
IB 91/12 & $0.986 \pm 0.02 \mathrm{c}$ & $0.8985 \pm 0.037 \mathrm{c}$ & $0.8423 \pm 0.024 \mathrm{a}$ \\
IB 103/12 & $1.369 \pm 0.09 \mathrm{a}$ & $0.7085 \pm 0.043 \mathrm{~d}$ & $0.7527 \pm 0.035 \mathrm{~b}$ \\
IB 111/12 & $1.035 \pm 0.05 \mathrm{c}$ & $0.8564 \pm 0.081 \mathrm{c}$ & $0.7909 \pm 0.034 \mathrm{~b}$ \\
IB 119/12 & $0.821 \pm 0.04 \mathrm{~d}$ & $0.8270 \pm 0.066 \mathrm{c}$ & $0.6518 \pm 0.024 \mathrm{c}$ \\
\hline CV (\%) & 11.3 & 13.6 & 10.2 \\
\hline
\end{tabular}

${ }^{(1)}$ Means followed by equal letters, in the columns do not differ significantly by the Scott-Knott test, at $5 \%$ probability. ${ }^{(2)}$ Infected control, plants inoculated with $S$. sclerotiorum. ${ }^{(3)}$ Control, plants not inoculated with either pathogen or strains of Trichoderma spp. CV, coefficient of variation. 
were present, showing the potential of these strains to reduce deleterious effects of the pathogen. Similar results were obtained by Ojaghian (2011), who showed that several species of Trichoderma reduced disease severity caused by S. sclerotiorum on potato (Solanum tuberosum L.) in a greenhouse experiment and also reduced disease incidence in field conditions.

Sclerotinia sclerotiorum can cause an average reduction of $46 \%$ in above-ground dry matter of soybean plants when seeds are inoculated with the pathogen (Botelho et al., 2013). In the conditions of the present study, reductions of up to $32.6 \%$ were observed (Table 3). However, positive effect of Trichoderma spp. on the growth of soybean plants in the presence of S. sclerotiorum has been reported by Guareschi et al. (2012), who found an increase in root system dry matter of up to $44.9 \% 60$ days after emergence. Therefore are reports of growth promotion by Trichoderma spp. in the absence of pathogens for other plant species such as tomato (Solanum lycopersicum L.) (Fontenelle et al., 2011), common bean (Phaseolus vulgaris L.) (Pedro et al., 2012), cucumber (Cucumis sativus L.) (Silva et al., 2011), and Arabidopsis sp. (Korolev et al., 2008). This beneficial effect has been attributed to many factors such as protection against rhizosphere pathogens, hormone production, increase of growth and development of the root system, improved absorption and translocation of mineral nutrients and

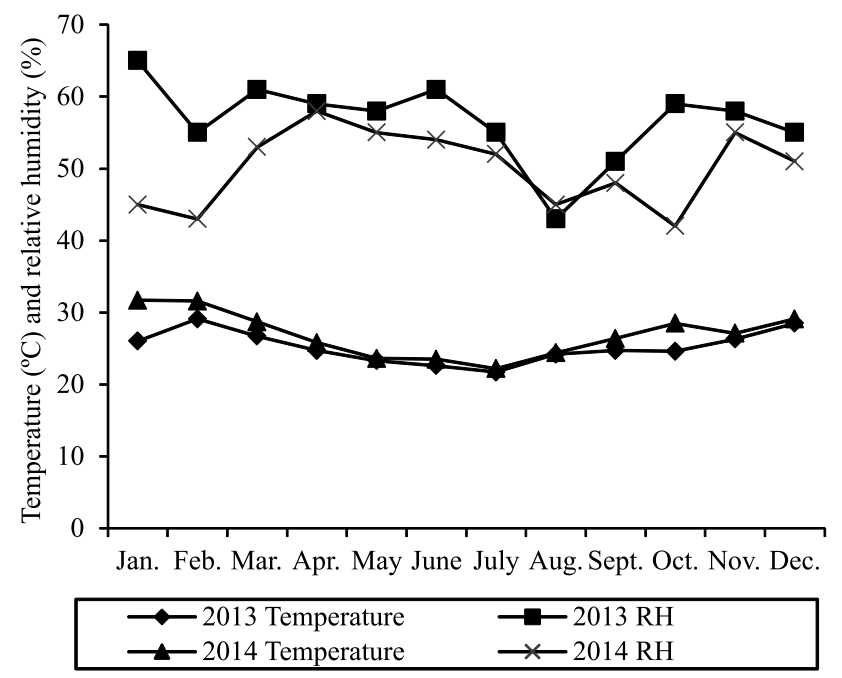

Figure 3. Monthly average temperatures and relative humidity in the municipality of São Paulo, in 2013 and 2014, according to IAG/USP (Boletim..., 2015). increase of solubility and availability of micronutrients (Contreras-Cornejo et al., 2009).

In the greenhouse experiments, white mold symptoms on inoculated soybean plants could not be observed. Ideal conditions for white mold occurrence are high humidity, temperatures between 15 and $25^{\circ} \mathrm{C}$, and low light incidence (Fischer et al., 2014). The lack of one of these factors can delay or interrupt disease progress. During our experiments, maximum average temperatures were $22.6^{\circ} \mathrm{C}$ in June $2013,28.5^{\circ} \mathrm{C}$ in December 2013 , and $31.7^{\circ} \mathrm{C}$ in January 2014, with relative humidity around 50\% (Figure 3). These conditions may not have favored symptom manifestation induced by the pathogen. Likewise, Guareschi et al. (2012) did not observe disease symptoms on the soybean plants inoculated with $S$. sclerotiorum due to the high temperatures (above $26^{\circ} \mathrm{C}$ ) during the experimental period.

At the end of the biological control experiments, it was confirmed that all strains of Trichoderma spp. were able to colonize the root system of soybean plants. This is considered an important feature for Trichoderma to act as a biological control agent or to promote plant growth since it allows competing for space or nutrients with soil pathogens (Samuels,

Table 3. Relative growth of 'Pintado' soybean (Glycine max) on substrate infested with Sclerotinia sclerotiorum in the presence or absence of strains of Trichoderma spp. based on above-ground dry matter weight.

\begin{tabular}{|c|c|c|c|c|c|c|}
\hline \multirow[t]{2}{*}{ Treatment } & \multicolumn{2}{|c|}{ Growth (\%) } & \multicolumn{2}{|c|}{ Growth (\%) } & \multicolumn{2}{|c|}{ Growth (\%) } \\
\hline & $*$ & $* *$ & $*$ & $* *$ & * & ** \\
\hline Infected control ${ }^{(1)}$ & 0.00 & -16.56 & 0.00 & 21.27 & 0.00 & -32.67 \\
\hline Control $^{(2)}$ & 19.83 & 0.00 & -17.54 & 0.00 & 48.26 & 0.00 \\
\hline IB $10 / 12$ & 2.75 & -14.23 & 28.77 & 56.16 & 24.47 & -16.12 \\
\hline IB $07 / 01$ & 30.26 & 8.73 & 61.76 & 96.17 & 37.13 & -7.59 \\
\hline IB $30 / 12$ & 21.77 & 1.65 & 8.58 & 31.68 & 42.66 & -3.87 \\
\hline IB $37 / 12$ & 33.40 & 11.36 & 15.18 & 39.68 & 46.99 & -0.95 \\
\hline IB $62 / 12$ & 13.63 & -5.14 & 27.78 & 54.96 & 67.31 & 12.75 \\
\hline IB $91 / 12$ & 12.36 & -6.21 & 2.34 & 24.11 & 63.24 & 10.00 \\
\hline IB 103/12 & 56.06 & 30.27 & -19.30 & -2.14 & 45.88 & -1.70 \\
\hline IB $111 / 12$ & 17.97 & -1.52 & -2.45 & 18.30 & 53.28 & 3.29 \\
\hline IB $119 / 12$ & -6.38 & -21.85 & -5.80 & 14.24 & 26.32 & -14.88 \\
\hline
\end{tabular}

(1) Infected control, plants inoculated with S. sclerotiorum. ${ }^{(2)}$ Control, plants not inoculated with either pathogen or strains of Trichoderma spp. *Calculated by comparison with infected control plants. **Calculated by comparison with control plants.

Pesq. agropec. bras., Brasília, v.52, n.12, p.1140-1148, dez. 2017 DOI: $10.1590 / \mathrm{S} 0100-204 \mathrm{X} 2017001200002$ 
2006). Furthermore, colonization allows an intimate and complex interaction with the plant through direct contact and internal colonization of root tissues (Hermosa et al., 2012).

The phylogenetic tree constructed with the TEF sequences of the strains of Trichoderma spp. of the present study and sequences retrieved from the GenBank allowed species identification (Figure 4). Strains IB 62/12, IB 103/12, and IB 111/12 belong to T. koningiopsis; strains IB 10/12, IB 37/12, and IB 91/12 belong to T. asperelloides; strains IB 07/01 and
IB 30/12 belong to T. atroviride; and strain IB 119/12 belongs to $T$. virens. These species have already been reported as biocontrol agents for $S$. sclerotiorum (Ethur et al., 2005; Matroudi et al., 2009; Ojaghian, 2011; Lopes et al., 2012).

The obtained results show the potential of strains of Trichoderma spp. for the biological control of white mold of soybeans. Further research in field conditions are required to select the most suitable strains for commercial product formulation and registration.

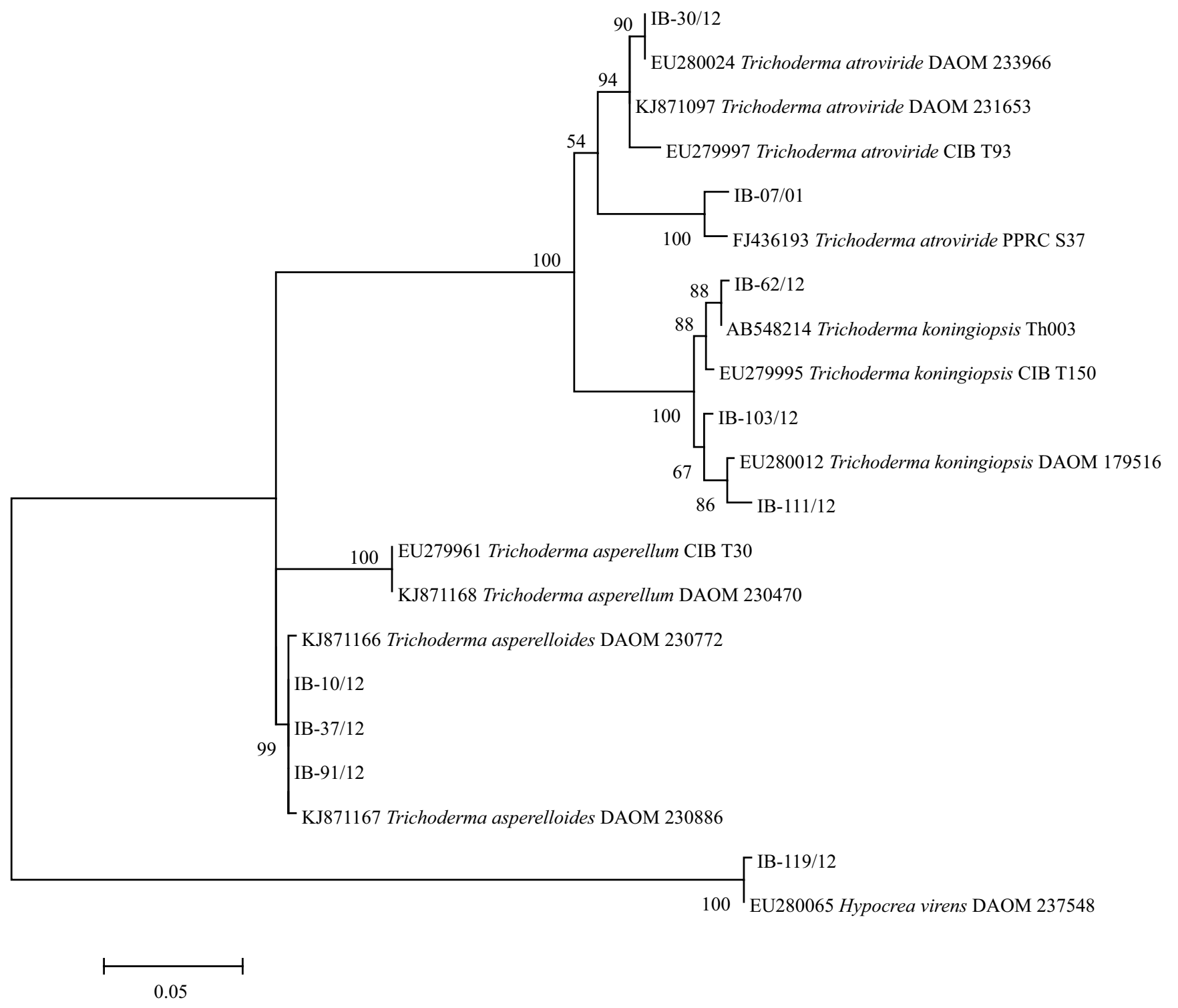

Figure 4. Phylogenetic tree constructed by the maximum likelihood method based on Kimura 2-parameter model with sequences of the translation elongation factor (TEF) from strains of the present study and sequences retrieved from the GenBank. Values next to branches show bootstrap values in percentage for 1000 repetitions. 


\section{Conclusions}

1. Among 120 strains of Trichoderma spp., 22 resulted in $100 \%$ inhibition of Sclerotinia sclerotiorum sclerotia germination in vitro.

2. Nine strains showed the ability to protect soybean (Glycine max) seed germination and plant growth from deleterious effect of the pathogen in at least one experiment.

3. The best performing strains were identified as T. koningiopsis, T. asperelloides, T. atroviride, and T. virens.

\section{Acknowledgments}

To Bio Germany, for the financial support.

\section{References}

ABDULLAH, M.T.; ALI, N.Y.; SULEMAN, P. Biological control of Sclerotinia sclerotiorum (Lib.) de Bary with Trichoderma harzianum and Bacillus amyloliquefaciens. Crop Protection, v.27, p.1354-1359, 2008. DOI: 10.1016/j.cropro.2008.05.007.

AKRAMI, M.; GOLZARY, H.; AHMADZADEH, M. Evaluation of different combinations of Trichoderma species for controlling Fusarium rot of lentil. African Journal of Biotechnology, v.10, p.2653-2658, 2011. DOI: 10.5897/AJB10.1274.

BARDIN, S.D.; HUANG, H.C. Research on biology and control of Sclerotinia diseases in Canada. Canadian Journal Plant Pathology, v.23, p.88-98, 2001. DOI: 10.1080/07060660109506914.

BENÍTEZ, T.; DELGADO-JARANA, J.; RINCÓN, A.M.; REY, M.; LIMÓN, M.C. Biofungicides: Trichoderma as a biocontrol agent against phytopathogenic fungi. In: PANDALAI, S.G. (Ed.). Recent research developments in microbiology. Trivandrum: Research Signpost, 1998. v.2, p.129-150.

BJÖRKMAN, T.; BLANCHARD, L.M.; HARMAN, G.E. Growth enhancement of shrunken-2 (sh2) sweet corn by Trichoderma harzianum 1295-22: effect of environmental stress. Jounal of the American Society for Horticultural Science, v.123, p.35-40, 1998.

BOLETIM climatológico anual da estação meteorológica do IAG/ USP: 2014. São Paulo: IAG/USP, v.17, 2015.

BOMFIM, M.P.; SÃO JOSÉ, A.R.; REBOUÇAS, T.N.H.; ALMEIDA, S.S. de; SOUZA, I.V.B.; DIAS, N.O. Avaliação antagônica in vitro e in vivo de Trichoderma spp. a Rhizopus stolonifer em maracujazeiro amarelo. Summa Phytopathologica, v.36, p.61-67, 2010. DOI: 10.1590/S0100-54052010000100011.

BOTELHO, L. da S.; ZANCAN, W.L.A.; MACHADO, J. da C.; BARROCAS, E.N. Performance of common bean seeds infected by the fungus Sclerotinia sclerotiorum. Journal of Seed Science, v.35, p.153-160, 2013. DOI: 10.1590/S2317-15372013000200003.

BROTMAN, Y.; LANDAU, U.; CUADROS-INOSTROZA, A.; TAKAYUKI, T.; FERNIE, A.R.; CHET, I.; VITERBO, A.;
WILLMITZER, L. Trichoderma-plant root colonization: escaping early plant defense responses and activation of the antioxidant machinery for saline stress tolerance. PLoS Pathogens, v.9, e1003221, 2013. DOI: 10.1371/journal.ppat.1003221.

CONSOLO, V.F.; MÓNACO, C.I.; CORDO, C.A.; SALERNO, G.L. Characterization of novel Trichoderma spp. isolates as a search for effective biocontrollers of fungal diseases of economically important crops in Argentina. World Journal of Microbiology and Biotechnology, v.28, p.1389-1398, 2012. DOI: 10.1007/s11274-011-0938-5.

CONTRERAS-CORNEJO, H.A.; MACÍAS-RODRÍGUEZ, L.; CORTÉS-PENAGOS, C. LÓPEZ-BUCIO, J. Trichoderma virens, a plant beneficial fungus, enhances biomass production and promotes lateral root growth through an auxin-dependent mechanism in Arabidopsis. Plant Physiology, v.149, p.1579-1592, 2009. DOI: $10.1104 /$ pp.108.130369.

ETHUR, L.Z.; BLUME, E.; MUNIZ, M.; SILVA, A.C.F. da.; STEFANELO, D.R.; ROCHA, E.K. da. Fungos antagonistas a Sclerotinia sclerotiorum em pepineiro cultivado em estufa. Fitopatologia Brasileira, v.30, p.127-133, 2005. DOI: 10.1590/ S0100-41582005000200004.

FERRAZ, L.C.L.; CAFÉ FILHO, A. Efeito da adição de fubá no meio de produção de escleródio e outros fatores influenciando na formação de apotécios de Sclerotinia sclerotiorum. Fitopatologia Brasileira, v.23, p.364-369, 1998.

FISCHER, I.H.; FILETTI, M. de S.; CRUZ, J.C.S.; BUENO, C.J. Efeito da temperatura e reação de genótipos de quiabeiro ao mofo branco. Summa phytopathologica, v.40, p.49-53, 2014. DOI: 10.1590/S0100-54052014000100007.

FONTENELLE, A.D.B.; GUZZO, S.D.; LUCON, C.M.M.; HARAKAVA, R. Growth promotion and induction of resistance in tomato plant against Xanthomonas euvesicatoria and Alternaria solani by Trichoderma spp. Crop Protection, v.30, p.1492-1500, 2011. DOI: 10.1016/j.cropro.2011.07.019.

GARCIA, R.A.; JULIATTI, F.C. Avaliação da resistência da soja a Sclerotinia sclerotiorum em diferentes estádios fenológicos e períodos de exposição ao inóculo. Tropical Plant Pathology, v.37, p.196-203, 2012. DOI: 10.1590/S1982-56762012000300006.

GÖRGEN, C.A.; SILVEIRA NETO, A.N. da; CARNEIRO, L.C.; RAGAGNIN, V.; LOBO JUNIOR, M. Controle do mofo-branco com palhada e Trichoderma harzianum 1306 em soja. Pesquisa Agropecuária Brasileira, v.44, p.1583-1590, 2009. DOI: 10.1590/ S0100-204X2009001200004.

GUARESCHI, R.F.; PERIN, A.; MACAGNAN, D.; TRAMONTINI, A.; GAZOLLA, P.R. Emprego de Trichoderma spp. no controle de Sclerotinia sclerotiorum e na promoção de crescimento vegetativo nas culturas de girassol e soja. Global Science and Technology, v.5, p.1-8, 2012.

HERMOSA, R.; VITERBO, A.; CHET, I.; MONTE, E. Plantbeneficial effects of Trichoderma and of its genes. Microbiology, v.158, p.17-25, 2012. DOI: 10.1099/mic.0.052274-0.

HERNANDEZ CASTILLO, F.D.; BERLANGA PADILLA, A.M.; GALLEGOS MORALES, G.; CEPEDA SILLER, M.; RODRIGUEZ HERRERA, R.; AGUILAR GONZALES, C.N.; CASTILHO REYES, F. In vitro antagonist action of Trichoderma 
strains against Sclerotinia sclerotiorum and Sclerotium cepivorum. American Journal of Agricultural and Biological Sciences, v.6, p.410-417, 2011. DOI: 10.3844/ajabssp.2011.410.417.

KOROLEV, N.; RAV DAVID, D.; ELAD, Y. The role of phytohormones in basal resistance and Trichoderma-induced systemic resistence to Botrytis cinerea in Arabidopsis thaliana. BioControl, v.53, p.667-683, 2008. DOI: 10.1007/s10526-007-9103-3.

LOPES, F.A.C.; STEINDORFF, A.S.; GERALDINE, A.M.; BRANDÃO, R.S.; MONTEIRO, V.N.; LOBO JUNIOR, M.; COELHO, A.S.G.; ULHOA, C.J.; SILVA, R.N. Biochemical and metabolic profiles of Trichoderma strains isolated from common bean crops in the Brazilian Cerrado, and potential antagonism against Sclerotinia sclerotiorum. Fungal Biology, v.116, p.815824, 2012. DOI: 10.1016/j.funbio.2012.04.015.

LUCON, C. M. M. Trichoderma no controle de doenças de plantas causadas por patógenos de solo. São Paulo: Instituto Biológico, 2008. (Instituto Biológico. Comunicado técnico, 77).

MATROUDI, S.; ZAMANI, M.R.; MOTALlEBI, M. Antagonistic effects of three species of Trichoderma sp. on Sclerotinia sclerotiorum, the causal agent of canola stem rot. Egyptian Journal of Biology, v.11, p.37-44, 2009.

OJAGHIAN, M.R. Potential of Trichoderma spp. and Talaromyces flavus for biological control of potato stem rot caused by Sclerotinia sclerotiorum. Phytoparasitica, v.39, p.185-193, 2011. DOI: 10.1007/s12600-011-0153-9.

OUSLEY, M.A.; LYNCH, J.M.; WHIPPS, J.M. Effect of Trichoderma on plant growth: a balance between inhibition and growth promotion. Microbial Ecology, v.26, p.277-285, 1993. DOI: $10.1007 / \mathrm{BF} 00176959$.

PEDRO, E.A. de S.; HARAKAVA, R.; LUCON, C.M.M.; GUZZO, S.D. Promoção do crescimento do feijoeiro e controle da antracnose por Trichoderma spp. Pesquisa Agropecuária Brasileira, v.47, p.1589-1595, 2012. DOI: 10.1590/S0100204X2012001100005.

REITHNER, B.; IBARRA-LACLETTE, E.; MACH, R.L.; HERRERA-ESTRELLA, A. Identification of mycoparasitismrelated genes in Trichoderma atroviride. Applied and Environmental Microbiology, v.77, p.4361-4370, 2011. DOI: 10.1128/AEM.00129-11.

SAMUELS, G.J. Trichoderma: systematics, the sexual state, and ecology. Phytopathology, v.96, p.195-206, 2006. DOI: 10.1094/ PHYTO-96-0195.
SCHUSTER, A.; SCHMOLL, M. Biology and biotechnology of Trichoderma. Applied Microbiology and Biotechnology, v.87, p.787-799, 2010. DOI: 10.1007/s00253-010-2632-1.

SHOUKOUHI, P.; BISSETT, J. Preferred primers for sequencing the 5 ' end of the translation elongation factor 1- $\boldsymbol{\alpha}$ gene (eEF1a1). 2009. Available at: $<$ http://www.isth.info/ methods/method.php?method_id=9>. Accessed on: Dec. 102014.

SILVA, F. de A. S.; AZEVEDO, C.A.V. de. A new version of the Assistat - Statistical Assistance Software. In: WORLD CONGRESS ON COMPUTERS IN AGRICULTURE, 4., 2006, Orlando. Proceedings. Reno: American Society of Agricultural and Biological Engineers, 2006. p.393-396.

SILVA, V.N. da; GUZZO, S.D.; LUCON, C.M.M.; HARAKAVA, R. Promoção de crescimento e indução de resistência à antracnose por Trichoderma spp. em pepineiro. Pesquisa Agropecuária Brasileira, v.46, p.1609-1618, 2011. DOI: 10.1590/S0100204X2011001200005.

SMITH, A.; BELTRÁN, C.A.; KUSUNOKI, M.; COTES, A.M.; MOTOHASHI, K.; KONDO, T.; DEGUCHI, M. Diversity of soil-dwelling Trichoderma in Colombia and their potential as biocontrol agents against the phytopathogenic fungus Sclerotinia sclerotiorum (Lib.) de Bary. Journal of General Plant Pathology, v.79, p.74-85, 2013. DOI: 10.1007/s10327-012-0419-1.

SMOLIŃSKA, U.; KOWALSKA, B.; KOWALCZYK, W.; SZCZECH, M.; MURGRABIA, A. Eradication of Sclerotinia sclerotiorum sclerotia from soil using organic waste materials as Trichoderma fungi carriers. Journal of Horticultural Research, v.24, p.101-110, 2016. DOI: 10.1515/johr-2016-0012.

TAMURA, K.; STECHER, G.; PETERSON, D.; FILIPSKI, A.; KUMAR, S. MEGA6: Molecular Evolutionary Genetics Analysis version 6.0. Molecular Biology and Evolution, v.30, p.27252729, 2013. DOI: 10.1093/molbev/mst197.

TANČIĆ, S.; SKROBONJA, J.; LALOŠEVIĆ, M.; JEVTIĆ, R.; VIDIĆ, M. Impact of Trichoderma spp. on soybean seed germination and potential antagonistic effect on Sclerotinia sclerotiorum. Pesticidi i Fitomedicine, v.28, p.181-185, 2013.

ZANCAN, W.L.A.; MACHADO, J. da C.; SOUSA, B.F.M. de; MATOS, C. de S.M. de. Crescimento micelial, produção e germinação de escleródios de Sclerotinia sclerotiorum na presença de fungicidas químicos e Trichoderma harzianum. Bioscience Journal, v.28, p.782-789, 2012.

Received on March 17, 2016 and accepted on March 20, 2017

Pesq. agropec. bras., Brasília, v.52, n.12, p.1140-1148, dez. 2017

DOI: 10.1590/S0100-204X2017001200002 